\title{
Prosperity and Social Inequalities: Montes Claros, How to Plan an Intermediary City in Brazil
}

\author{
Jean-Claude Bolay \\ CODEV (Center for Cooperation and Development) \& LaS UR (Urban Sociology Laboratory), EPFL (Swiss Federal \\ Institute of Technology, Lausanne), Lausanne, Switzerland \\ Email: jean-claude.bolay@epfl.ch
}

Received 13 May 2016; accepted 25 June 2016; published 28 June 2016

Copyright (C) 2016 by author and Scientific Research Publishing Inc. This work is licensed under the Creative Commons Attribution International License (CC BY). http://creativecommons.org/licenses/by/4.0/

\section{Open Access}

\section{Abstract}

According to international statistics, nearly $50 \%$ of the world's urban population live nowadays in cities of less than 500,000 inhabitants. These small and medium-sized cities play a role of intermediation between rural regions, local economy and more extensed urban networks, with three spheres of influence: micro-regional, national and international. In many of these "intermediate cities", the main problem to reinforce them in their action is a lack of financial and human resources for managing the city in a comprehensive way, in order to tackle the demographic and spatial extension of these urban settlements, and avoid an increase of social segregation and fragmentation of territory. The example of Montes Claros, in the State of Minas Gerais, Brazil, helps us understand how a city of nearly 400,000 inhabitants, at the center of an economically prosperous region, tackles these issues through a current process of urban planning, having to take into account its historical, social and spatial context. Like most Brazilian and Latin American cities, Montes Claros-which acts as a transit hub at the State and national levels-is a rapidly growing intermediary city that has seen continued economic growth over the past two decades. However, this industrial and business growth has not resulted in a more inclusive distribution of the urban population. Considering the resulting growth from rural migration and new urban residents, the urban area of Montes Claros remains fragmented territorially, with neighborhoods more or less well equipped and served by public transport depending on the socio-economic status of their inhabitants. The current process of urban planning raises many issues, among them three crucial elements to improve in order to re-introduce planning as appropriate approach and instruments able to guide the decision makers towards the future of a city and its region: a medium and long-term vision for Montes Claros, its hinterland and the Northern region of Minas Gerais; a biased perception of Montes Claros in which only the dense areas in the city center are taken into account, with suburban areas still disconnected from the rest of the city and poorly integrated; a participatory process of urban planning involving all stakeholder and population, from the diagnostic till the definition of priorities in terms of urban policies, strategies and investments. 


\section{Keywords}

\section{Intermediary Cities, Intermediation, Social Disparities, Spatial Fragmentation, Urban Planning, Urban Priorities, Montes Claros, Minas Gerais, Brasil}

\section{Introduction}

The concept of "intermediary city" was, until recently, seldom used to talk about the changes taking place in less known, less studied, medium-sized cities all over the world. As they are still largely unexplored, their advantages and disadvantages relative to big cities - which are inherently connected with the global urban networks and dominant both economically and politically at the national level—remain largely unknown (Sassen, 2001; Tayor et al, 2007). The emblematic example of Montes Claros in the State of Minas Gerais in Brazil helps us understand how a city of nearly 400,000 inhabitants at the center of an economically prosperous region, tackles problems of demographic growth through public policy, in order to resolve growing social, economic and planning disparities through an urban planning process adapted to historical, social and spatial context.

Cities are mainly defined by spatial and demographic criteria, with medium-sized cities being emblematic of the so-called "intermediary city." According to international statistics, nearly $50 \%$ of the world's urban population now live in cities of less than 500,000 inhabitants. Such cities are home to two-thirds of the urban population in Europe, half of the urban population in Africa, and a slightly smaller percentage in Latin America and Asia (United Nations, 2014). In emerging and developing countries, these cities face particular difficulties: less efficient public administrations, insufficient funds to meet social needs and a lack of skilled individuals to manage large projects. In more industrially and technologically advanced countries, intermediary cities long suffered the primacy of larger cities. The UCLG (The Global Network of Cities, Local and Regional Governments, 2013, 2016), whose World Conference in October 2016 will tackle this theme, made the same observation and, as an association of local and regional decision-makers, underlines the deficits these cities suffer. "These cities will require greater attention in the coming years, given that local governments must prepare for rapid urban growth and major challenges in the future: namely, political and financial dependence, limited capacity and scarce financial resources ${ }^{1}$ ”. Drawing on our previous studies on this question, (Bolay \& Rabinovich, 2004; Bolay et al., 2004), intermediary cities are defined based on a certain number of characteristics, with three spheres of influence: micro-regional, national and international. More specifically, we can identify "affected" intermediary cities (with a strong territorial position), "satellite" intermediary cities (close to larger cities), and "remote" intermediary cities (more closed vis-à-vis their surroundings due to their remote location (Nadou, 2010).

In developing countries, national governments have largely allocated service provision and fundraising to the lower tiers of the government, but without the necessary financial and human resources. Thus, residents of smaller cities suffer a marked disadvantage in terms of drinking water supply, waste disposal, electricity and schools compared to those of larger cities (Cohen, 2006). Notably, levels of infant and child mortality are proportional to city size, more important in larger cities (National Research Council, 2003). Moreover, urban poverty is clearly lower than in larger cities (Ferré et al., 2012). Small and medium-sized cities thus have time to address basic infrastructure and service needs, before the gap becomes too great. Hence, there are some advantages to being small.

Beyond population and surface area, intermediary cities are defined based on the interaction between a city and its surrounding environment (immediate and remote). Eight criteria can be identified (Bolay \& Rabinovich, 2004):

- Demographic: the natural growth rate and impact of migration;

- Economic: the city's competitiveness (production and retail), which in turn feeds the surrounding rural areas and national/international markets;

- Political and institutional: the city's decision-making power;

- Social, educational and health: the quantity and quality of services, inclusion of different socio-economic groups and social relationships that extend beyond the city;

- Environmental: use and management of natural resources and the intensity/degree of contamination linked to

${ }^{1}$ http://www.uclg.org/en/media/news/intermediary-cities-new-urban-agenda. 
urban activities;

- Equipment which is specialized and sophisticated enough to offer services to both the endogenous and exogenous population;

- Cultural and leisure: the emergence of new urban lifestyles reflects local cultures and influences;

- Spatial: urban planning, regional development projects and communication with other cities in the country.

Three spheres of influence can be identified:

- The local and micro-regional scale, based on the relationships established between the intermediary city and its hinterlands;

- The national scale, due to the city's inclusion in the urban network and its role in the strategies of the State and economic actors;

- The international scale, due to the specific role the city plays in a given sector (import/export, tourism, transport, etc.).

Urban-rural interface is a strong element for intermediation between cities and their hinterlands. It is within this framework that the formers' multi-functionality can be seen as platforms for exchange between territories (sales of its agricultural production) and as service hubs for rural populations. They also serve as a relay for the upper strata of the administrative and economic apparatus. Socially and culturally, intermediary cities enjoy a privileged position in terms of social inclusion/cohesion and cultural belonging. Politically speaking, social conflicts are not as obvious as in larger cities. Economic globalization likewise offers new opportunities for intermediary cities, along with a certain degree of autonomy. In some cases, these cities actually prove more competitive than larger cities and, like the latter, benefit from major network supply (roads, telecommunications, etc.).

Given their demographic growth and economic potential, intermediary cities are critical for their regions, governing the economic flows that innervate and circumscribe migration from rural areas and serving as connection points within the urban network at the regional, national and even international levels.

As urban centers of rural regions, intermediary cities like Montes Claros play a key role in the rural-urban relationship balance, both as service providers for the entire population, from producers to consumers (Satterthwaite \& Racodi, 2003). This trend is not unique to Brazil, but rather can be observed in all emerging and developing countries, as Klaufus (2010) shows taking the examples of Guatemala and El Salvador. Thus, if public policies are well adapted to the context, these cities can play a critical role in the fight against poverty. Moreover, these cities are often overlooked for the potential host role they play for rural migrants, who rarely migrate directly from their birthplace to major cities, which explains their statistically higher demographic growth (Aguayo-Téllez et al., 2010; Romanos \& Auffrey, 2002).

Planning and governance of small and medium-sized cities must tailor regulations, planning and decisions to fit the specificity of the context (advantages, potential, weaknesses, risks, etc.). In many of these cities, the main problem is lack of financial and human resources for managing the city in a comprehensive way, not as a fragmented entity comprised of specific social, economic and political interests, which result in social and spatial inequalities. Through decentralization and increasing autonomy, global cities can now play a more decisive role at three different levels of territory: as regional decision-making centers, as a friendlier, safer alternative to larger cities and as affordable areas of economic development at national and international levels offering new opportunities for people and businesses (Bolay \& Kern, 2016).

\section{Montes Claros: Urban Intermediation in Northern Minas Gerais}

Brazil is now one of the most urbanized countries in the world. According to Soares (2006), this urbanization is relatively recent, starting in the early 1940s. In 1950, it was estimated that the rural population represented 64\% of the national population. Starting in the 1970s, this trend reversed, with the majority of the population becoming urban. In 2010, 84.4\% of the country's population (160.0 million people) lived in cities (IBGE, 2010). The country has 106 cities with more than 200,000 inhabitants (not including state capitals), representing 20.4\% of the national population and accounting for $27.7 \%$ of Brazil's GDP (Veja, 2011).

Originally founded in 1831 (ACI, 2012), Montes Claros is located between the $16^{\circ} 04^{\prime} 7^{\prime \prime}$ southern latitude and $43^{\circ} 41^{\prime} 56^{\prime \prime}$ and $44^{\circ} 13^{\prime} 01^{\prime \prime}$ longitude west of Greenwich in the northern part of the State of Minas Gerais (Figure 1), which has 89 municipalities (IBGE, 2010). According to the IBGE, it has a surface area of $3569 \mathrm{~km}^{2}$, 


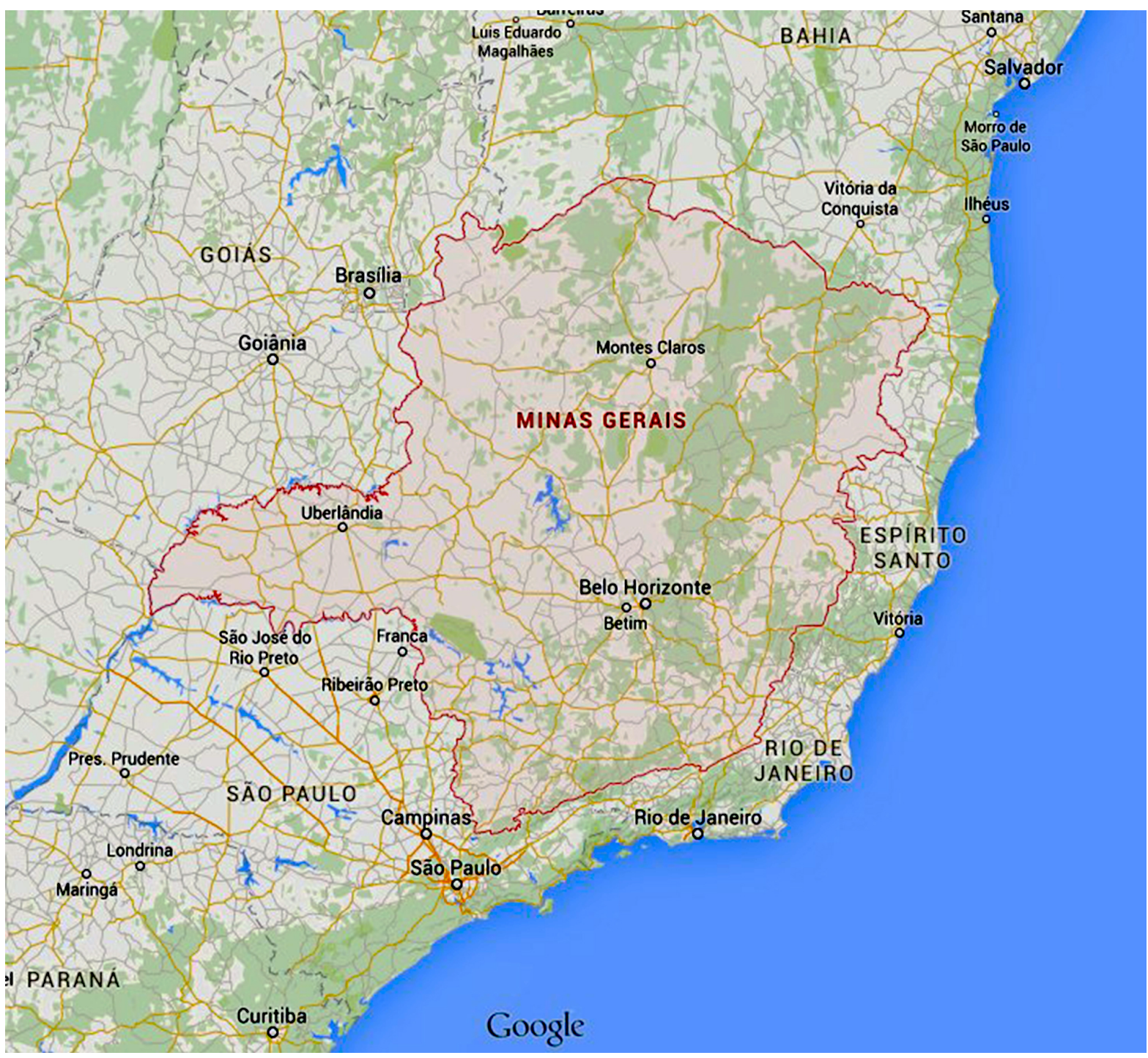

Figure 1. Geo-spatial location of Montes Claros (Google map, 2015).

including $97 \mathrm{~km}^{2}$ of urban territory corresponding to the urban perimeter ${ }^{2}$ and an average altitude of 638 meters. The average annual temperature is $24.2^{\circ} \mathrm{C}$, with two seasons: a hot, rainy season and a long, dry season (Gomez \& Lamberts, 2009). The average high temperature is $29.3^{\circ}$ and average low is $16.7^{\circ}$. The maximum temperature exceeds $40^{\circ}$ at times. The municipality of Montes Claros has existed since 1831, obtaining city status in 1857. The IBGE estimated the city's population at 361,915 in 2010 and 390,212 in 2014, with a population of 20.7 million in the State of Minas Gerais and 202.8 million in Brazil. Today, it is an urban hub for a region of roughly 2 million people (Prefeitura de Montes Claros, 2015).

Demographic growth for the municipal population is strong, with the overall population becoming increasingly urban in the past 50 years. In 1970, the municipal population totaled 116,486; 73\% was urban (Photo 1). In 1990, it numbered 250,002, 90.8\% of which was urban. In 2000, of the 306,947 inhabitants, $94.2 \%$ were urban (IBGE, 2000). With 10 districts and 134 neighborhoods, 94\% of Montes Claros's population now lives in urban areas (IBGE, 2015). This attraction to urban areas, linked in recent decades to the city's industrialization, has resulted in the arrival of masses of rural immigrants who settle-often informally-on the urban fringes.

For Soares de França and Ribeiro Soares (2007a), Montes Claros meets the criteria of an intermediate city. The

${ }^{2}$ http://en.wikipedia.org/wiki/Montes_Claros. 


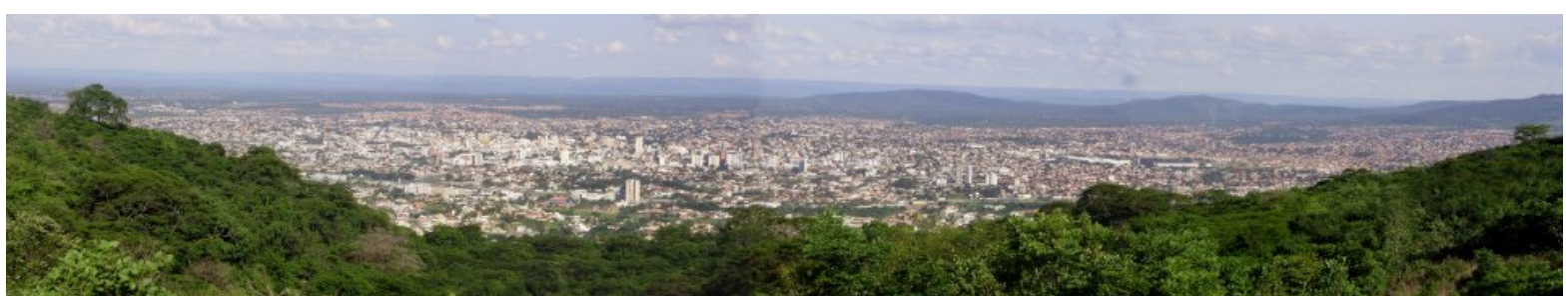

Photo 1. Panoramic view of Montes Claros (Jean-Claude Bolay, 2015).

authors emphasize, however, that "this consideration should not only be based on demographic criteria or the role the city plays at the regional level, but should also take into account its economic infrastructure and services”. 63\% are working age (15 - 59), and 7\% are aged over 60. In 1963, Montes Claros became the first northern municipality in the State to found an institution of higher education. Today, it has two public universities and 17 private higher education institutions, as well as several technical training schools (ACI, 2012), that serve a total of 30,000 students. Montes Claros also has a top-rate offering when it comes to the health and medical field, with eight hospitals, three polyclinics, 15 urban health centers and 20 rural centers. Most of these are public institutions, though several are managed privately ${ }^{3}$.

It is likewise useful to consider the complexity of the division of labour relative, among other things, to Montes Claros's geographical location and transportation/communication networks. Citing Sposito (2001), the authors add that this division of labour is not a strictly intra-urban dynamic but rather is interurban. To this we would add the importance of taking into account the urban-rural relationship (which, in Montes Claros's case, is an agricultural and residential hinterland that abuts Montes Claros), shopping centres and other services that are used by the entire urban and rural region, thus offering a privileged destination for rural migrant populations. However, as Esdras Leite (2010) points out, medium-sized cities with strong economic and demographic growth are increasingly facing housing supply issues.

Montes Claros's economy has, since the city's founding in the 19th century, been based on export of basic commodities, agriculture and breeding. However, industry has gradually succeeded in replacing these cornerstones (Soares Costa da Silveira, 2005). The service sector has also boomed, representing 66\% of the city's GDP in 1999 and 72\% in 2008, followed by the industry sector (25\%) and the primary sector (3\%) (Soares de França, 2012). The city's location-far from major cities like Belo Horizonte and Sao Paolo- and infrastructure have helped make it an important hub for the northern part of the State of Minas Gerais. This, in turn, has attracted numerous investments (undoubtedly facilitated by tax incentives) and funding for urban programs from both the state and federal governments (Soares de França, 2015). In 2015, the Prefect of Montes Claros cited the city as among the 20 medium-sized Brazilian cities whose economic growth surpassed $30 \%$ in the past decade. This would explain why the current economic crisis Brazil is facing, with a decrease of $3 \%$ in the national economy in $2015^{4}$, has impacted Montes Claros less than other intermediary cities ${ }^{5}$. The GDP was R\$3,815,101,000 in $2009^{6}$. This same year, Belo Horizonte, the State capital, had a GDP of R\$ 58,374,103,000 and an annual per capita GDP of R $\$ 24.365$ (IBGE, 2015). In 2013, Montes Claros increased its GDP to R \$ 7,053,746,000. In the same year, the GDP per capita reached R\$ 18,274. As such, Montes Claros has become Minas Gerais's $10^{\text {th }}$ wealthiest city $^{7}$, with strong growth in recent years Municipal government revenues totaled R\$ 723,069,000 in 2014, with annual growth of nearly $15 \%^{8}$. Montes Claros's consumption is equivalent to $25 \%$ of the State's entire northern region. The monthly per capita income is $\mathrm{R} \$ 647.92,48.23 \%$ higher than the average income in the northern part of the State. Montes Claros is home to 10,862 companies, which, in $2010^{9}$, provided jobs for 69,045 people.

Until the late 1980s, Montes Claros was considered above all an industrial city. In the 1990s, however, in-

\footnotetext{
${ }^{3}$ http://www.montesclaros.mg.gov.br/cidade/aspectosgerais/saude.htm.

${ }^{4}$ http://www1.folha.uol.com.br/mercado/2015/10/1690728-brasil-sofre-pior-corte-em-projecao-de-crescimento-do-fmi.shtml.

5http://www.montesclaros.mg.gov.br/agencia_noticias/2015/ago-15/not_04_08_15_4106.php.

${ }^{6} 200$ dollars at one real $=0,325$ US\$.

${ }^{7}$ http://www.deepask.com/goes?page=Confira-o-PIB---Produto-Interno-Bruto---no-seu-municipio.

${ }^{8}$ Roughly 273 million dollars. Exchange value in December 30th, 2014 was 2.65 R\$.

${ }_{9}^{9}$ For 2012, the Instituto Brasileiro de Geografia e Estatistica statistics give slightly different figures: 10,859 companies and 95,593 employees, with an average monthly salary of 2.1 times the minimum wage (set at 788 R\$ a month (537/256 US\$).
} 
vestments in the industry sector declined, causing many companies to close or relocate to other cities. Investments were largely redirected toward the service sector (trade, real estate, health and education, to name the key ones), changing Montes Claros's face forever. A new dynamic was born, reinforcing its status as a mediumsized city in a dynamic of strong regional/interurban interplay, and strengthening its position as an intermediary city and the centre of a key region in the State of Minas Gerais. Following to Soares de França's (2012) analysis, this could explain why Montes Claros's GDP rose significantly in recent years, with growth of $177 \%$ between 1999 and 2008, falling just short of the national rate (185\% for the same period, and 225\% for Minas Gerais). This trend has continued, with a gain of $40 \%$ between 2009 and $2012^{10}$. Nevertheless, the GDP per inhabitant is still below the national average, with 18,278 R\$ per inhabitant in Montes Claros versus 22,642 ${ }^{11}$ for nationally in 2015.

\section{Economic Growth and Social Changes in Monte Claros: The Verticalization of a City}

The economic boom of the 1970s, the fruit of a national strategy, resulted in major territorial and social changes and a restructuring of urban functions and the role of secondary cities in Brazil's urban network, creating new poles of attraction for national and foreign investment (de Oliveira \& Ribeiro Soarez, 2014; de Oliveira, 2009).

From the second economic and social national development plan was born the national support program for capitals and medium-sized cities, designed to financially support urban infrastructure, transport and economic revitalization projects. According to Amorim and Serras's (2001) definition, medium-sized cities are urbanized areas with an urban population of between 100,000 and 500,000 inhabitants. França et al. (article cited) add to this strictly demographic definition other criteria relative to infrastructure, economic diversity, cities' relationship with their rural hinterland and their role in Brazil's urban network.

This dynamic comes with an urban reform that dates back to the enactment of the new federal constitution in 1988, which includes a chapter on urban policy in Brazil and recognizes the autonomy of local governments legally, politically and financially. It also sets out guidelines for popular participation in decision-making processes $^{12}$. This was followed by the creation of the "city" status at the national level, which explicitly recognizes the (social) right to the city, in 2001. This status requires all cities of more than 20,000 inhabitants to develop a five-year master plan, and to follow certain mechanisms to guarantee the effective participation of citizens and associations in urban planning and management procedures.

The new legislation likewise imposes also aims to regularize consolidated informal settlements in private and public areas. The Ministry of Cities, created in 2003 under President Lula's mandate, founded two important initiatives that are still in effect today: a program to support sustainable urban land regularization and a national campaign for participatory municipal master plans.

In the early 1970s and 1980s, Montes Claros experienced spectacular spatial and demographic growth, notably through the development of new housing estates, often outside the framework of formal planning and more as a result of private investments than government planning. During this period, downtown Montes Claros grew vertically, with new service infrastructure appearing in addition to the renovation of public spaces, while other sectors fell into decline. With this came mobility issues, as the public transport supply did not provide service to all neighborhoods. This process intensified during the 1990-2000 period, especially in the city center along avenues with strong commercial and economic "potential" linked to a sharp rise in land prices and the restructuring of city streets into major traffic thoroughfares.

Today one easily distinguishes those housing estates inhabited by populations with high buying power in poor neighbourhoods (mainly in the east and north of the city). The same period saw the construction of many 10story-plus buildings (Photo 2). In 2011, changes to the law on socially vulnerable areas relaxed regulations for buildings with more than five floors. The same year, the municipality ratified a law allowing for the expansion of Montes Claros's urban perimeter, further facilitating the verticalization of the built fabric. This extension carried over into the city centre and northern part of the city with commercial buildings and rental units in coowned condominiums (Soares de França et al., 2014).

\footnotetext{
${ }^{10}$ http://www.deepask.com/goes?page=montes-claros/MG-Confira-o-PIB---Produto-Interno-Bruto---no-seu-municipio.

${ }^{11}$ The equivalent of $\$ 4683$ and $\$ 7358$ for 2016.

${ }^{12}$ This constitutional reform encourages a number of cities (in Porto Allegre, Recife and, closer to Montes Claros, Belo Horizonte for instance) to set up “urban conferences” and participatory budgetary processes via municipal laws (Fernandes, 2007).
} 


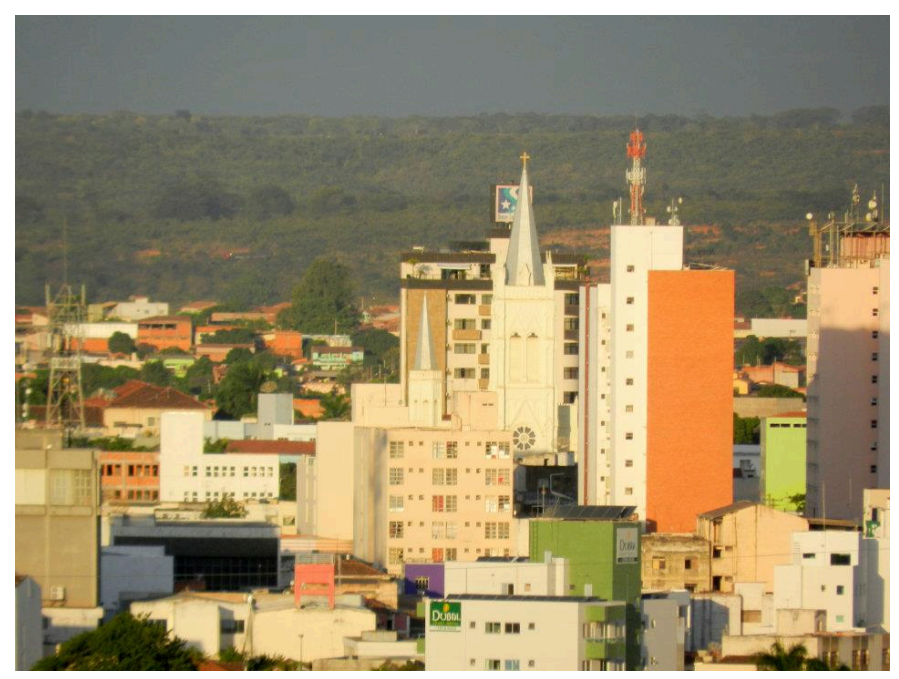

Photo 2. City district of Montes Claros (Jean-Claude Bolay, 2015).

This trend continues today and has become hard-wired in legal terms. From 2002 to 2001, the municipal authorities of Montes Claros produced several laws on land use in the municipality (Municipio de Montes Claros, 2009, 2011, 2015). As one sees on the map produced by Soares de França et al. (2014), the verticalization of the city-initially for residential purposes-gradually expanded to include commercial real estate in the more central areas of Montes Claros. Today, this trend continues in all those areas with high land value, to the benefit of families with strong buying power and businesses with high added value (Soares de França, 2015). For the authors, this trend negative could have an impact on the environment and quality of urban life. It also clearly marks the links between the public and private sectors (between the city government, on one hand, and large regional and national construction companies and investors, on the other). Analyzing the same process in other Brazilian cities, Cohn (2012) concludes that the verticalization of the real-estate supply also affects access, socially speaking. As purchase and rental prices climb, only the rich can afford to buy or rent apartments; small business owners cannot afford to rent commercial space, which, according to him, negatively affects job creation among small businesses and industries with large, low-wage workforces. Many other Brazilian cities, intermediary and large ones alike, are also witnessing the verticalization of their housing supply. This phenomenon goes hand in hand with their territorial expansion and social and cultural segregation that economically benefits the wealthier social classes ${ }^{13}$ and the commodification of city centers and residential areas with high land values, resulting in pronounced territorial segregation.

The verticalization debate, however, also has its roots in a planning model come down from the modernist movement that highlights such "constructive" solutions as a way of addressing issues of housing, infrastructure efficiency and economic vitality (Soares Gonçalves, 2004). For the author, promoters of this planning solution have, since World War II, highlighted synergies with business by a proximity effect, a more rational use of urban infrastructure (thanks to higher population densities) and the image of modernity and attractiveness these buildings represent. Meanwhile, its critics highlight energy overconsumption in a small portion of the territory, overexploitation of urban infrastructure and services due to a highly concentrated population at particular points in the city and a negative environmental impact in terms of shade and wind turbulence.

Technical solutions exist for making high buildings efficient in terms of energy and use of natural resources such as water, solar heat, etc. However, this requires significant investments in their design-which impacts production costs and commercial value- and flawless integration of these buildings in masterplans environmentally, demographically and infrastructurally. Such cases, however, are exceptional. Taking the example of Londres (UK), Appert (2008) points out that the highrise buildings popping up in countries all around the world (old, new, industrialized or emerging ones such as Brazil) are a sign of potential conflict between preservation and promotion of historic urban heritage and the shaking up of the urban form symbolically (what image of city do we want in a global and comparative perspective?). At the same time, such a context promotes economic growth,

\footnotetext{
${ }^{13}$ This is the case cited by Polidoro et al. (2012) for the city of Londrina, in Parana.
} 
job creation and social well-being. These tensions need to be managed carefully, given that the image of the city is, today, a real concern and tool of power, politics and collectiveness.

In light of these characteristics, Montes Claros may be considered the regional capital of northern Minas Gerais, and has thereby been equipped with economic, political and infrastructural services in areas like education, health, business and transport. Because of its strategic position, Montes Claros benefitted from public economic development programs, including tax incentives for companies that locate there, starting at the end of the 1970s. Like other medium-sized cities in Brazil, Montes Claros's development was reflected in a shift in rural migration- to its benefit, but to the detriment of larger Brazilian cities- and increased regional commuter traffic.

Parallel to these changes, however, a growing number of recent arrivals to the city are finding themselves in precarious housing conditions characterized by an impoverished population, insecure land tenure and a lack of urban facilities and services. Montes Claros reproduces the process of territorial and social division found in other similar cities in Brazil. Favelas can be found in $80 \%$ of medium-sized Brazilian cities, versus $40 \%$ in smaller cities of 20,000 to 100,000 inhabitants (Esdras Leite, 2010).

More generally, following the analysis of Leite \& Pereira (2005), the poverty level-74.7\% in 1970 and 55.45\% in 1991-has dropped considerably in recent decades in Montes Claros (versus $33.17 \%$ in 2001). The wealthiest $20 \%$ of the population controls $66 \%$ of the wealth. A good indicator of the spatial distribution of poverty is reflected in the price of land that, in 2004, ranged from $1251 \mathrm{R} \$$ downtown to 28 - $89 \mathrm{R} \$$ in the suburbs (Figure 2). In wealthy neighborhoods, monthly incomes ranged from 400 to $1200 \mathrm{R} \$$ on average, while those in poor neighborhoods ranged from 30 to $80 \mathrm{R} \$$. Urban infrastructure and services also point to socioeconomic disparities. While water supply and sewage drainage systems exist across the entire territory (though not all homes are necessarily connected to them), public transport, street lighting and tree planting are grossly lacking in poor neighborhoods.

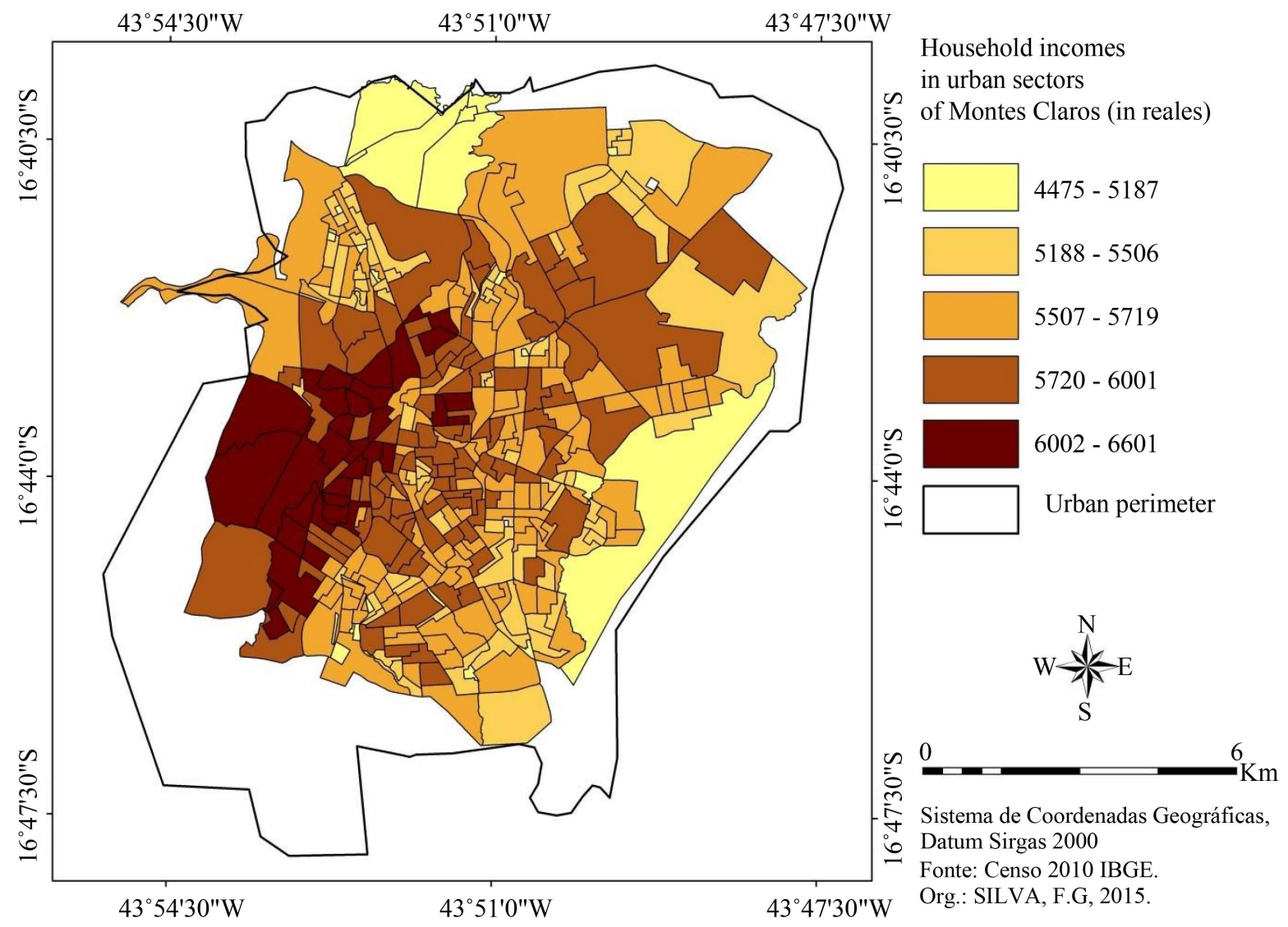

Figure 2. Houselholds incomes in Montes Claros (Municipalidade de Montes Claros e laboratorio de geoprocessamento Unimontes; Francielle Gonçalves Silva et al., 2015). 
Echoing the analyzes of different authors, Feitosa et al. (2011) point out that several factors contribute to urban spatial segregation, including the job market and its socio-economic impact (salary level, job insecurity, etc.) and increasing poverty among poor workers and sub-standard living conditions. Conversely, the expansion of the private property market may result in a concentrating of investment in neighborhoods of high standing, thus benefitting areas reserved for the privileged, at the expense of the poor. Finally, the lack of government action and failure to implement inclusive social urban policies hiders the creation of social housing subdivisions. However, such segregation is unique neither to Montes Claros nor to Brazil.

Some authors, such as Smets \& Salman (2008), show that spatial segregation is a multi-faceted phenomenon that is not only the matter of a divide between rich and poor neighborhoods (between "gated communities" and "slums", in its extremes), but also concerns migration, ethnic divisions, social exclusion and economic precarity. In the Global South, as in the Global North, the prevailing economic globalization and neo-liberalism tend to minimize the role of the State and urban communities. Tensions arise from both the pressure of budgetary allocations between public authorities (national, regional and municipal) and the fierce competition among cities worldwide. Cities-both large and intermediary-are increasingly influenced by the impact of global networks (financial, physical, demographic and intellectual) which, in turn, determine the speed and extent of political, social, economic and cultural changes at the local, urban and regional levels (Castañeda et al., 2011; McCann, 2008; Rossi et al., 2007; Roberts, 2005; Robinson, 2002).

Like most Brazilian and Latin American cities, Montes Claros-which acts as a transit hub at the State and national levels-is a rapidly growing intermediary city that has seen continued economic growth over the past two decades and, according to statistics, a gradual decrease in poverty. However, this development has not resulted in a more balanced or homogeneous distribution of the urban population in spatial and planning terms. Considering the resulting growth from rural migration and new urban residents, the urban area of Montes Claros remains fragmented territorially, with neighborhoods more or less well equipped and served by public transport depending on the socio-economic status of their inhabitants. Soares de França and Ribeiro Soares (2007b) cite Montes Claros as emblematic of a medium-size city acting as a regional capital for the northern part of the state of Minas Gerais. We would add that it is an intermediary city, as this centrality operates at several spatial scales (i.e. at local and micro-regional levels (flows of agricultural products and the marketing/processing of these products, health and educational facilities for the urban population as well as urban and rural populations from the rest of the state). This centrality also has national and international dimensions, primarily through economic dynamics that promote the creation of production companies of Brazilian and foreign firms (Alpargatas, Clairmont, Cotenor and Coteminas, to name a few Brazilian companies active in Montes Claros. Nestlé, RPC, Fiat, Novonordisk, Ciments Lafargue and many other foreign firms also operate in the industrial zone, with production for the domestic market and for continental and global export, as in the case of Nestlés Dolce Gusto capsules $^{14}$ ).

\section{Urban Planning Process in Montes Claros: Changes or Continuity?}

Since the 2000s, Montes Claros has adopted a new, two-part masterplan: an urban development masterplan and a municipal housing plan, as part of the Habitar Brasil program (since 2002), with funding from the InterAmerican Development Bank. The program aims to improve poor housing conditions in metropolitan and urban areas in Brazil, with the goal of supporting those who earn less than three times the minimum wage living in poor neighborhoods. Major investments in Montes Claros have attempted to mitigate infrastructural deficiencies in these new residential areas, aiming to reorganize land, social and urban planning issues in a coordinated manner, notably through involvement in sanitation, energy, transport and school facilities (Soares de Souza \& Soares de França, 2011).

A fieldwork was organized in May 2015 and May 2016, in cooperation with Professor Iara Soares de França ${ }^{15}$ from the Universidade Estadual of Montes Claros $\left(\right.$ UNIMONTES $^{16}$ ) and her colleagues and co-workers. We met

\footnotetext{
${ }^{14}$ http://g1.globo.com/mg/grande-minas/noticia/2013/10/fabrica-da-alpargatas-e-inaugurada-em-montes-claros.html. http://www.istoedinheiro.com.br/noticias/economia/20041006/coteminas-melhor-empresa-brasil/16658.

http://www.em.com.br/app/noticia/economia/2015/12/17/internas_economia,718415/nestle-inaugura-fabrica-de-capsulas-de-cafe-em-montes -claros.shtml, http://areaguas.com/rpc-vai-construir-fabrica-em-minas-gerais/, http://exame.abril.com.br/negocios/noticias/fiat-industrial-construra-de-fabrica-em-montes-claros, http://www.novonordisk.com.br/fale-conosco.html.

${ }^{15}$ http://www.ppgeo.unimontes.br/laeur.php, http://buscatextual.cnpq.br/buscatextual/visualizacv.do?id=K4756289U7.

${ }^{16}$ http://unimontes.br/.
} 
with 30 individuals representing different local sectors in order to get their views on current key urban issues, the different players involved, the urban planning process and its objectives and implementation.

This work gave us an updated portrait of Montes Claros environmentally, spatially, economically and socially, which we will now explore in light of the current planning process being implemented by the urban authorities.

\subsection{Heterogenity and Urban Priority Issues to Resolve}

Urban planning and development issues are inevitably dealt with by representatives of various physical, social, administrative and organizational institutions. Their heterogeneity highlights the multidimensional nature of regional organization and urban planning, which decision-makers and operators tend to reduce to their material aspects. While the latter are imminently important, the fact that they are the result of ad hoc political decisions, and that changes made are not sustainable unless they are developed as part of a long-term vision via an inter-actor process, is too often overlooked.

We will start by looking at the spatial aspects of urban planning, facilities and services, in order to then address the opinions of our respondents, irrespective of their identities,

Montes Claros is an intermediary Brazilian city according to demographic and spatial criteria, and based on its connection with its hinterland and the national economy. The municipal authorities consider it an urban agglomeration, but do not truly consider all facets of its regional influence. Within municipal limits, what matters to the authorities is not the rural areas - which are considered primarily as a source of labor supply for urban businesses and not part of a rural-urban entity - but rather the urban space. As the population of this heavily urbanized area grows, neighboring rural areas depopulate due to urban immigration. Policy makers and professionals do not veritably address this issue often raised by scientists. Rather, only social service agents and NGO representatives point out this dichotomy by showing how people in rural areas lack services of all kinds.

At the urban level several shortcomings were observed, notably the regulation of the water issues (Photo 3). Given the climate, Montes Claros requires not only a drinking water supply-which can today be found in almost all urbanized areas-but also technical measures for controlling floods during the high rainy season. Rain and flooding obviously have a negative environmental impact. However, periodic water shortages in certain areas stem not only from problems in the existing networks, but are also the result of accelerated deforestation due to illegal construction of new habitats in the surrounding hills (Photo 4). The sprawling homes of the landed class and luxury housing developments are gradually threatening the region's ecological balance, as water struggles to find its way to the water table and instead runs off into the lower parts of the city.

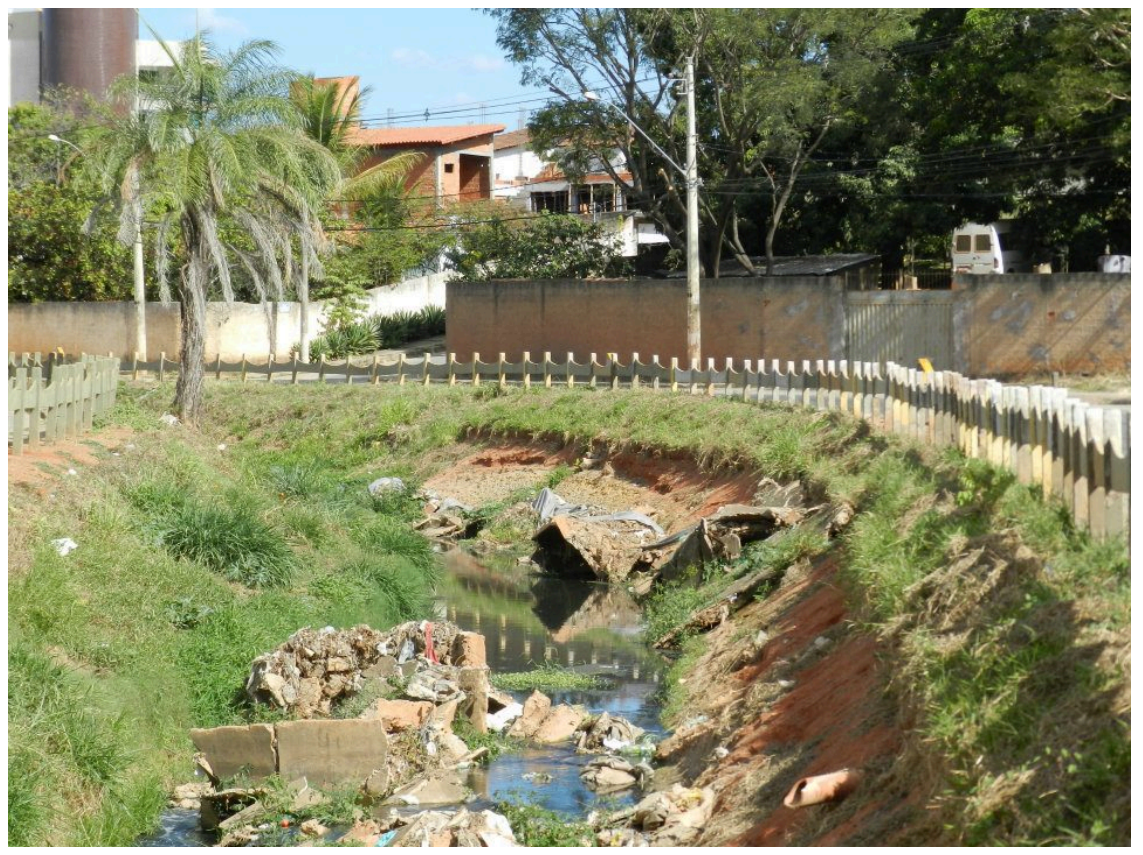

Photo 3. Contaminated urban river (Jean-Claude Bolay, 2015). 


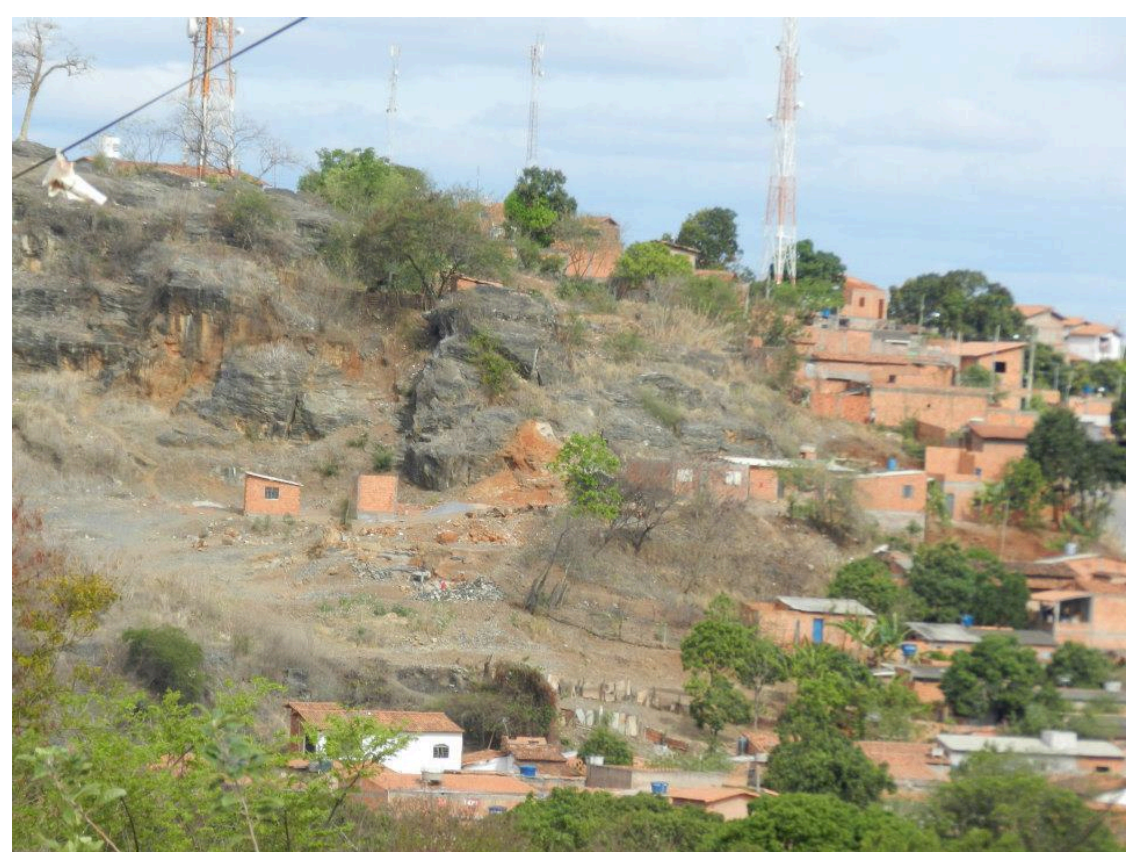

Photo 4. Recently built outskirts of Montes Claros (Jean-Claude Bolay, 2015).

Other technical questions relate mainly to: the electric power supply (inadequate in certain suburbs), harvesting, recycling and solid waste treatment ${ }^{17}$ (while landfills exist, they do not comply with environmental protection standards and have a negative impact), land use (which is poorly regulated), seismic monitoring and protection measures (in the event of earthquakes), and transport systems.

All of this is the indirect result of the rapid growth of new social housing developments funded by national and state programs (Photo 5 \& Photo 6) and luxury housing for the city's elite. An urban mobility master plan exists, but has not been fully implemented. Moreover, Montes Claros, as a regional hub, faces transport issues that challenge both regional mobility and the infrastructure and services that link the city and surrounding countryside. Montes Claros is a hub for the storing and redistribution of agricultural products, which generates considerable lorry traffic. It is also a commercial and industrial center, where many individuals live in rural areas and commute to the city to work.

During our social housing development visits, we observed that public transport service was scarce and sporadic at best. To our knowledge, there is no recent and comprehensive study on the topic. Homeowners with modest incomes must simply accept the reality of this sub-standard transport service and "make do" with costly solutions such as shared taxis, motorbikes, etc., as they often work at some distance. Public amenities are also rare in these new developments. Schools, playgrounds, social and health centers are not systematically planned or built in these new suburbs. The small, identical houses are all lined in rows, sometimes with a small yard, but no shared or common space. Simply put, the poor benefit from programs that marginalize them spatially. While affordable housing is still of paramount importance, it should not in itself be the objective of urban planning.

At a higher level of urban development, several respondents pointed out the fact that the land registry, if it exists, is not made public, thus enabling the political authorities and certain power elites to interpret it without consulting the public and the fact that, in many neighborhoods, the urban master plan is simply not applied. According to one respondent, favelas like those found in Rio or elsewhere in Brazil do not exist in Montes Claros. However, in the words of another respondent, the problem is more general, and therefore more serious when one considers that more than 140 of Montes Claros's neighborhoods are still unzoned, rendering coherent and appropriate organization of public and private initiatives in these areas impossible. These essentially parcelingtype projects all have but without any strategic place in the medium or long-term development of the city (Photo 7). Most of the issues addressed by Montes Claros's master plan in the medium and long terms have regional

\footnotetext{
${ }^{17}$ According to SERENCO (2015), there is no garbage collection in neighbourhoods outside the city centre. Families dispose of their trash themselves, either by burning it or throwing it in vacant lots. Recycling and organic composting do not exist.
} 


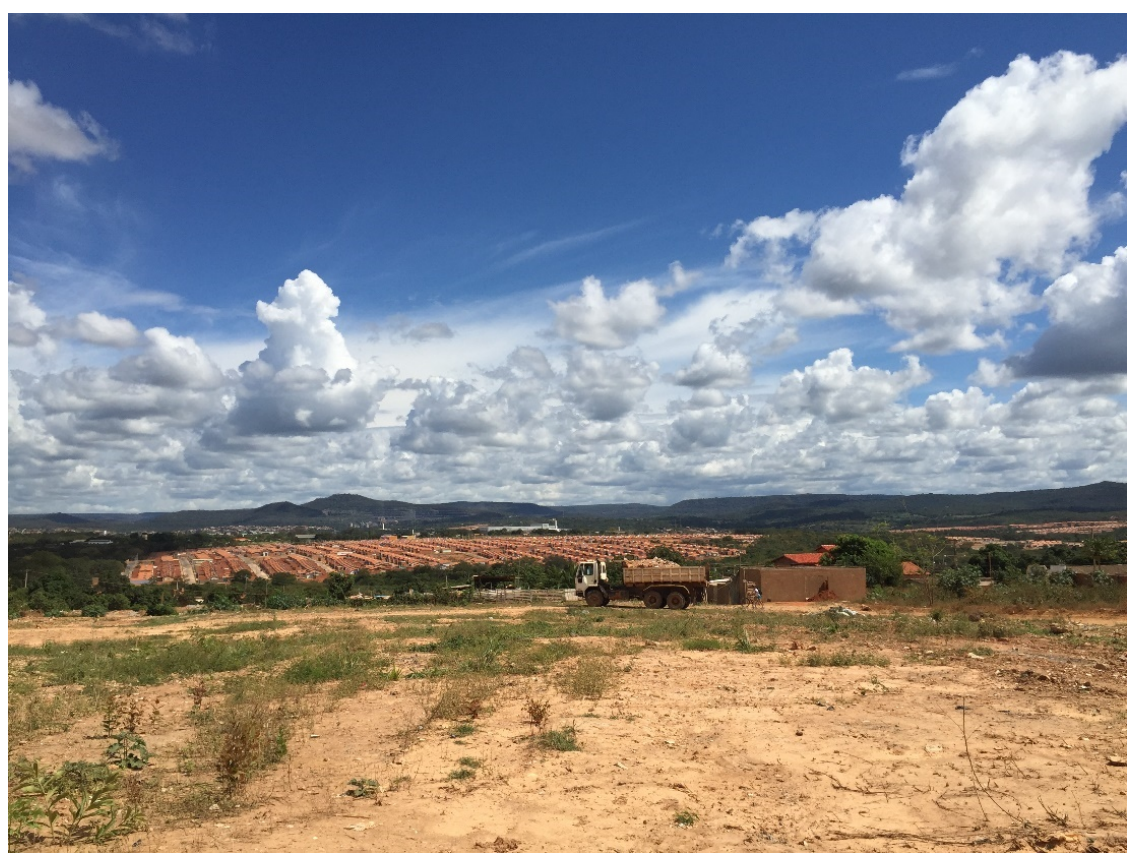

Photo 5. New social housing settlement in Montes Claros (Jean-Claude Bolay, 2015).

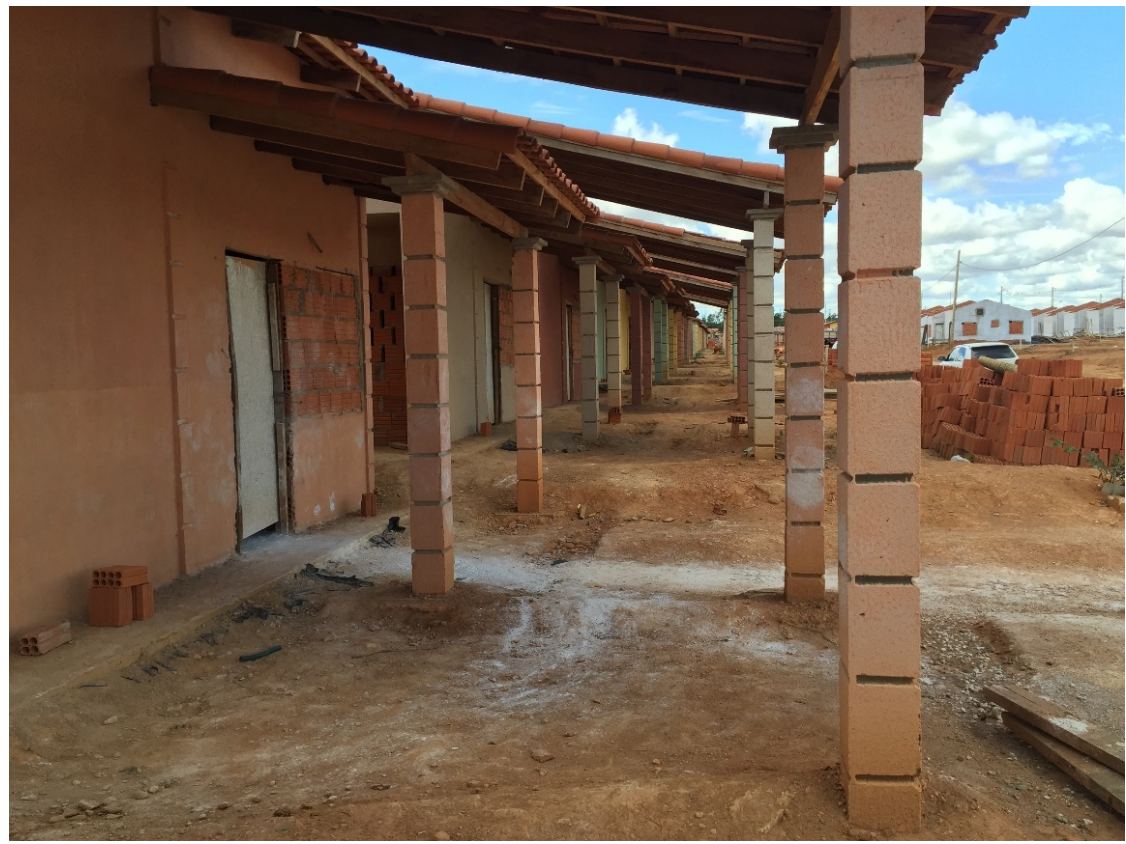

Photo 6. Details of new social houses (Jean-Claude Bolay, 2015).

impact. Hence, a city plan should likewise (and always) be a regional plan that takes into account both migration flows, in some cases definitive, as the population of the urbanized area increases, and in other cases in the form of daily commuting between downtown Montes Claros and the surrounding rural areas.

A number of societal issues also help shed light on Montes Claros's functioning. Notably, what emerged from the interviews is that Montes Claros no longer has any civic culture to create social cohesion and identity. For some interviewees, Montes Claros and its region are no longer a collective reference, both in terms of its historic and built heritage (which is largely neglected and enthusiastically destroyed to make room for an avatar of "modernity") and in terms of its natural environment (which is little developed and threatened by continued 


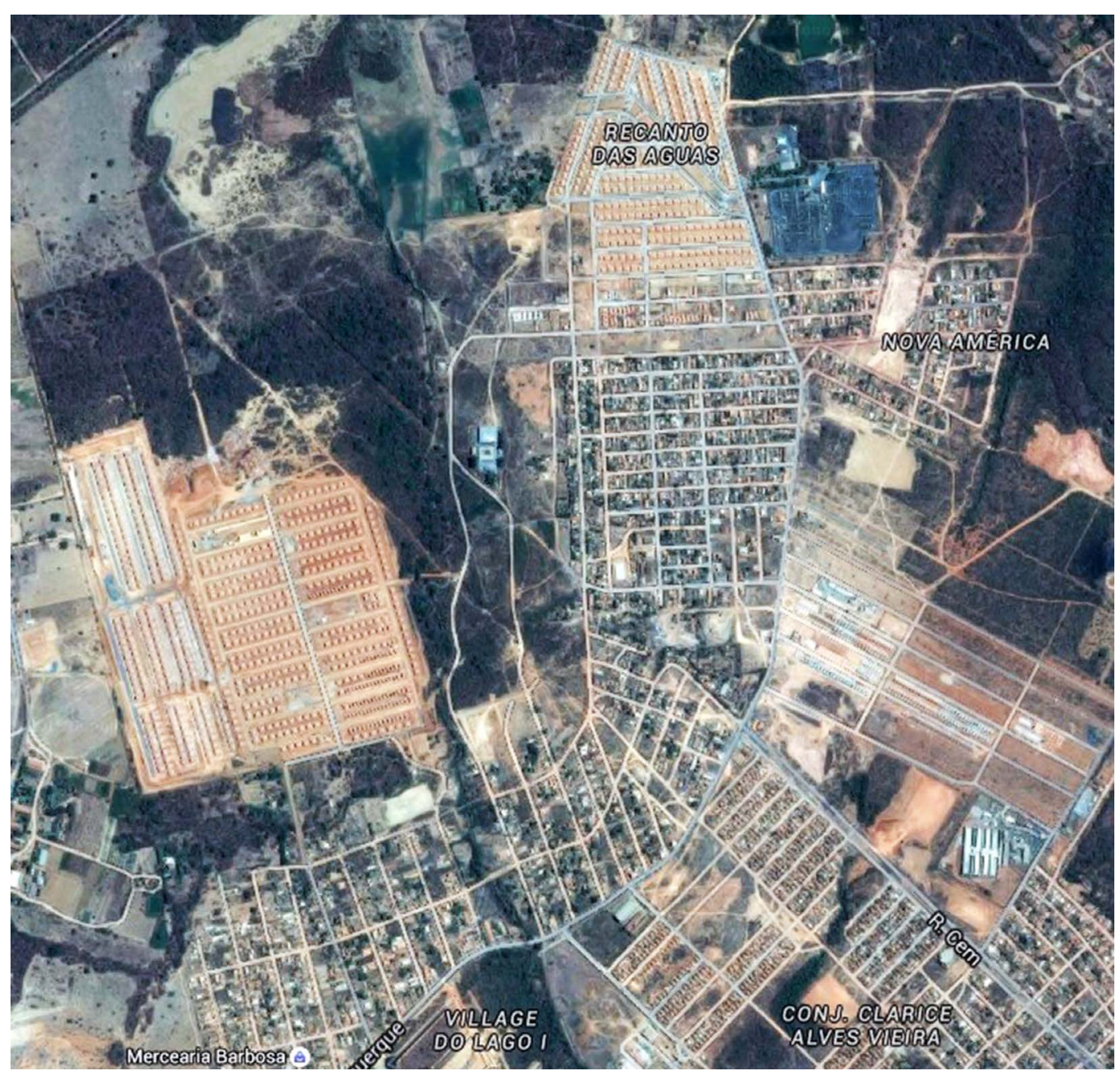

Photo 7. New suburb neighbourhoods in Montes Claros (Google map, 2015).

deterioration of its forest-covered hills and its rivers). What prevails are personal and political interests that couple political action and financial advantages to benefit the local elite.

Such first fruits generate biases in the very creation of participatory processes because the political authorities, in creating a new urban development plan, limit participation to a select elite that includes economic operators, academics and professional associations. In other words, the many collective interest groups, NGOs and other associations are left out. Fundamentally, the process is not systematically based on the involvement of inhabitants from every neighborhood. Informational meetings are indeed organized but are, at best, advisory campaigns and, at worst, pure partisan propaganda. Here we find an example of top-down management, a far cry from participatory, bottom-up governance based on social involvement and the identification of shared priorities between the population and political representatives.

All those interviewed felt that urban planning should target the welfare of people from all walks of life, with an emphasis on alleviating the challenges faced by the poor and destitute, whose numbers are increasing and whose living conditions are gradually deteriorating. A symptomatic example of this is "street people." We counted nearly 300 homeless people "living" in public areas in downtown Montes Claros. No municipal policy has been put in place for this highly vulnerable population (i.e. shelters, food banks, health services or care for mothers and children). The only initiatives designed on their behalf exist thanks to volunteers (religious groups in most cases). The same holds true for the 750 - 800 junk "recyclers," who are among Montes Claros's poorest and who manage to find enough to survive on in the 600 tons of waste the city produces each week.

Social issues are also part of the dichotomy between Montes Claros and its rural hinterland. For a total popu- 
lation of nearly 400,000 inhabitants, Montes Claros has 11 centros de referencia de assistência social (CRAS), which assist roughly 5000 individuals per year. The respondents felt this was insufficient, especially in the municipality's rural areas where there is only one CRAS for a population of some 20,000 inhabitants across 176 rural communities and over an area of nearly $3370 \mathrm{~km}^{2}$ (versus the $97 \mathrm{~km}^{2}$ of urban area). This flagrant proportion questions the organization of public services across the municipality.

Other societal aspects have mainly to do with the existing political system and modes of governance.

As in any democratic country, the alternation of power has repercussions both at the policy level and in the organization of administrative and technical services. The fact that the entire administrative framework changes with each change of Prefect negatively impacts Montes Claros's ability to function; instead of taking into account previous projections, the overwhelming tendency is to start from scratch in order for the new leadership to leave its mark. Moreover, in a shortsighted vision of profitability, collusion between political authorities, local elites and big industry offers no prospect for social, urban or environmental sustainability.

These comments and critiques reveal an urban society in crisis, faced with the changes taking place at the demographic, infrastructural, environmental and cultural levels. Respondents expressed some disappointment with regard to the inconsistencies in the regional planning process and their negative impact on the urban structure and social organization of the population, highlighting among other things the problem of mismanagement.

\subsection{The Current Planning Process: Players in Motion}

Montes Claros's current urban planning process offers an excellent opportunity to identify the key players in this dynamic and explore how governance is organized in the city and surrounding region.

Before reviewing our respondents' comments, we will briefly summarize how Montes Claros's government is organized as, according to the law, the entity responsible for urban planning but nonetheless answerable to official bodies, both at the state and at federal levels.

As mentioned earlier, the official birth of the city dates back to 1831, with its 2,000 inhabitants. The name "Montes Claros" was that of one of the haciendas in the region. Until 1760, the land belonged to indigenous groups, but was later conquered by gemstone searchers and subsequently cleared by farm owners.

A municipal government divided between a legislative power (a chamber of 23 councilors elected for a period of 4 years $^{18}$ ) and an executive power (led by a prefect, currently Ruy Adriano Borges Muniz of the Partido Republicano Brasileiro) governed the city following 1930. Muniz, also a member of the Legislative Assembly of Minas Gerais, is seconded by vice-prefect José Vicente Medeiros.

In 2010, Montes Claros had a total of 238,405 voters, a figure that has sharply increased in recent years ${ }^{19}$.

According to respondents, the city council consists of a planning council, an environmental council and a land issues council, to which outside experts are invited to voice their opinions in an advisory capacity.

The critiques lean in two directions:

- First, the implementing of decisions made by the council falls on technical teams and administration members who have neither a guaranteed job in the long term, as in many cities (and thus are more dependent on the political leaders in power), nor attractive salaries. This can lead to conflicts between individuals and departments, which does little to foster continuity in the implementing of decisions;

- Secondly, political changes in the city's administration have direct political repercussions on the continuity of urban alternatives, with each new mayoral team seeking to set itself apart from its predecessors and to "leave its mark".

- As in all democracies, elected city council members are chosen largely on a partisan basis, without necessarily having any proven policy experience or technical skills in the area in question. As such, council members often find themselves in situations of dependence, both in terms of their party and with respect to executive power.

The result is a lack of autonomy for the local legislation relative to the city government and a lack of transparency in the choices made by the latter. To remedy this situation it is imperative to clarify the rules, state the prerogatives of the council versus those of the city government more clearly, and make decisions involving the city's future more explicit and public.

Montes Claros’s current master plan dates from 2001 but is, in fact, a copy of that of Belo Horizonte, the cap-

\footnotetext{
${ }^{18}$ No details on the political division in the House.

${ }^{19}$ According to the online journal Quarta, July 23, 2010.
} 
ital of Minas Gerais. As such, no real consideration made for the specificities of Montes Claros. In reality, what still determines urban planning in Montes Claros is the master plan implemented in 1970, which itself was preceded by a plan developed in 1954 .

Brazilian law requires that every city have a master plan and sector plans for roads, accessibility, drainage and sanitation. For respondents, the main issue here is that these plans should not serve as simple models simply to be replicated without discernment. Rather, they should address the specific challenges of each city by reflecting the views and needs of their users.

This explains why, for those present at the discussion, the current process is extremely important. The process was developed by the Prefecture (the local government), in cooperation with three regional academic institutions (FIP, UNIMONTES and FUNORTE ${ }^{20}$ ). The collaboration took the form of weekly meetings on the topics addressed by the plans, in conjunction with all the municipal secretariats. These meetings have led to proposals on future land tenure law and an updating of the city's zoning. Based on these documents, an online debate ${ }^{21}$ was launched and open meetings held with the public to gather critiques and suggestions. From these exchanges should emerge a set of guidelines that will be revisited by the municipality and its academic partners. The process was to have been completed in August 2015, but subsequent reports suggest that the deadline has been extended.

A conference attended by numerous professionals and academics based on this collaboration was held in May 2015. The main theme: "Urban planning, renewable energy and shared implementation: sustainable cities."

In September 2015, the municipal council of Montes Claros studied the updated master plan, which included 13 guidelines: health, social protection, social development, land use, environment, solid waste management and cleanliness, economic development, education, culture, sports and leisure, urban mobility, infrastructure and sanitation, roads and public lighting ${ }^{22}$-an impressive list indeed. Once the document is finalized, potential crossover and complementarity among the topics will be identified and overall coherence ascertained. Certain issues raised during the discussions, such as taxes and taxation, public security, energy and historical heritage, were eliminated from the list.

According to information from UNIMONTES, this preliminary plan, designed by Montes Claros technicians, was to be submitted for public review during the course of three public hearings, which took place in October 2015, in the central districts covered by the plan. The first hearing, opened by the prefect, provided a very descriptive overview of the plan, without topical hierarchy. The second focused on social and health issues, and the third on land and urban land uses. However, there is no indication of the number of people who attended these sessions. The documents posted online by the Municipality still lack a reference text that introduces the 13 sector chapters and lays out the authorities' vision for the coming years in terms of outlook, objectives, priorities, implementation schedule and expected results. Article 1 of the 2921 Act of August 27, 2001 ${ }^{23}$ (currently in effect) offers several key elements in its design and objectives: the plan is considered the basic tool for the physical, social, economic and administrative aspects of urban development policy that targets sustainable development and the community's aspirations through government action and private initiatives. It will be interesting to determine later on whether the goals of the 2015 plan were based on the same precepts.

It is therefore not a participatory process with regard to the master plan, but rather served to validate the decisions already made by the authorities as reflected in the provisional plan.

In parallel to the creation of the master plan, a sanitation plan was also developed but is for the time being, according to respondents, a mere compilation of information without any real strategy.

The first advantage respondents cited in the discussions is that local services are well organized and have the staff/consultants needed to design a master plan for Montes Claros.

For some, the current process is headed in the right direction and will help in developing appropriate proposals for the city. They felt there should nonetheless be a project coordinator (an urban planner or architect) heading the unit, which does not seem to be the case.

However, the current process raises many issues. To begin, it is impossible to discern the authorities' medium- and long-term vision, which would be helpful in streamlining the urban planning. Furthermore, the authorities' perception of Montes Claros is biased as it only takes into account the dense areas in the city center.

\footnotetext{
${ }^{20}$ Faculdades Integradas Pitágoras-FIPMoc, Universidade Estadual de Montes Claros, e Faculdades Unidas do Norte de Minas.

${ }^{21}$ There is no clear evidence of this online debate on the City of Montes Claros's official website.

${ }^{22}$ http://www.montesclaros.mg.gov.br/planodiretor/planodiretor2015.htm.

${ }^{23}$ Also on the municipality web page.
} 
The rapidly growing outskirts and suburban areas are still disconnected from the rest of the city and are poorly integrated in this prospective exercise. In the future, Montes Claros must be seen as an urban hub for northern Minas Gerais, in a kind of urban/rural/interurban interplay that involves environmental, social, educational and housing issues. All neighborhoods and people cannot be dealt with in the same way; specific needs and priorities must be taken into account.

While there is undeniably cooperation with national and regional authorities in the implementation of the current plan, it is not a participatory master plan in the eyes of many respondents. Instead of a top-down process involving outside experts-in itself is not a reprimandable approach - the new plan would start from the needs and concerns of neighborhoods and their inhabitants, which urban priorities would then reflect. It would also be beneficial for academic partners to be seen as producers of scientific works whose results may contribute to the debate and influence planners and policy makers.

The lack of integration and democratic participation are indirectly reflected in the "assistance-oriented" political culture: many programs assist vulnerable populations (bolsa familiar, FIES-Fomento ao programa de governo do ensino superior) but are inherently designed as emergency safeguards and therefore do not resolve long term funding problems.

A final, yet critical, considering in the current process is that, once completed, the master plan should be supported by enabling legislation. Without it, the plan cannot be fully functional.

\section{Conclusion: Key Planning Guidelines for an Intermediary Brazilian City}

With a population of nearly 400,000 inhabitants and a municipal budget of 368 million dollars in 2016 (and growing steadily), Montes Claros is a perfect example of an intermediary Brazilian city. While it would be incorrect to describe it as a poor city, the urban population is highly segregated; one third of the city's population is poor, and the wealthy-who represent $20 \%$ of the population-control $66 \%$ of the local wealth. This fragmentation of the social fabric is also reflected in the more than 140 unregulated neighborhoods and 50,000 people living in makeshift housing conditions, again resulting in extreme differences in income (400 - $1200 \mathrm{R} \$$ per month in the city center to 30 - 80 in poor neighborhoods).

In addition to these socio-economic and territorial disparities, two other major problems exist. The first is the depletion of natural resources due to advanced deforestation and periodic flooding of central neighborhoods, a problem that largely results from the construction of new housing developments (social and luxury), wherein the environmental impact of these forms of urbanization, which have become increasingly popular in the past 20 years, are not fully considered. The second is the lack of regional integration of the municipality's rural hinterlands. These areas, where services and telecommunications are still rudimentary, are gradually being abandoned as purely agricultural region and progressively transformed in new peri-urban settlements.

To address this situation, the local authorities are in the process of developing a new master plan. The Brazilian Constitution, updated in 2015, specifies in Articles 182 and $183^{24}$ that "urban development policy led by the municipal government, according to the general guidelines established by the law, is designed to order the full development and social functions of the city, and to ensure the welfare of its people." A master plan approved by the City Council is mandatory for all cities with more than 20,000 inhabitants should serve as an instrument for enforcing federal law adapted to the local context in the form of municipal laws (following the precepts of the federal law) to resolve issues relative to taxes on land, real estate value, parceling and expropriation.

In addition, there is also a constitutional instrument in the form of a law regulating the status of the city in Brazil (Senado Federal, 2001 \& 2004). The first Article of this federal document states that public standards for social welfare will regulate the use of urban land for the good, security and well-being of citizens and environmental balance. As such, the plan aims to create a sustainable city, including a right to urban land, housing, infrastructure, services, transport and employment for everyone. This requires democratic management and the involvement of the people and associations in the formulating, implementing and supporting of plans, urban development programs and other projects.

The project, launched in 2014, is extremely important considering the transformation Montes Claros has undergone in recent decades and the need rethink the municipal territory and surrounding region vis-à-vis population growth and economic change. Rural areas are depopulating as the urban population gradually increases.

\footnotetext{
${ }^{24}$ Constituição da República Federativa do Brasil Atualizada até a Emenda Constitucional, No. 88, May 7, 2015 (http://www.planalto.gov.br/ccivil_03/constituicao/constituicao.htm).
} 
Furthermore, economically speaking, Montes Claros has arguably experienced its third revolution. Until mid1900’s it was primarily a center for the agro-processing industry and agricultural trade before slowly becoming a center for industry - which it is still today- and home to many companies.

In the past twenty years, Montes Claros has come to be seen as a service hub for the surrounding area, particularly as regards higher education institutions and preeminence in the health sector. Its many commercial enterprises also offer a wide range of services. However, as incomes rise, social segregation increases. Today, the municipality is facing the issue of social exclusion, with an increasing proportion of the urban population living in economic insecurity and relative marginalization, both geographically and socially. These are key issues for a comprehensive urban plan whose aim is to not only act spatially.

This ongoing process-which is nearing its completion-may be can be seen as an associative process, but not a veritably participatory one. City Hall has indeed teamed up with private agencies and representatives from different sectors (universities, representatives from the economic community, etc. and the ad hoc committees of the City Council), but without including the public in the initial phase of democratic debate. It is only now in the final phase that the provisional results, which will determine the guidelines for future planning, will be presented and discussed in the more urbanized areas of the city. This exclusive approach has received considerable criticism from "outsiders”, particularly volunteer organizations and social groups, who were not invited to participate in the process from the beginning. For them, this denotes a certain authoritarianism on the part of the public authorities (especially the Mayor, who has close ties with business and industry circles), who have not seized the opportunity the new plan affords to engage in an open dialogue with the public to better understands its needs and desires. While some skepticism was noted among those interviewed, it is still too early to judge the impact. Rather, what counts is the impact these debates will have on the final product, which must be approved not only by the local authorities but by the State as well. It remains for the government to prove its willingness to change its course of action by acknowledging the reactions that arise from these neighborhood forums, and develop proposals include outlying areas and their populations in economic growth and social redistribution dynamics.

In conclusion, though Montes Claros cannot be described as a "poor city", it can be described as a mediumsized city that, like many other cities in Brazil, is experiencing the kind of unbalanced growth that is typical of what one can see in cities around the world. Brazil has become one of the most segregated countries in the world, an emblem of economic globalization in a growing struggle between global regions and cities (nationally and internationally) and strategies to improve social cohesion and cultural/economic integration politically and in terms of urban planning. Urban planning is not merely a technical or spatial endeavor; it must aim to help cities and regions adapt to larger context in order to respond to the needs of all of their people through projections over time.

Returning to our definition of the “intermediary city” (Bolay \& Kern, 2016; Bolay \& Rabinovich, 2004) and the objectives of urban and regional planning that is tailored to the context both spatially and humanistically, we concluded that the first goal must be eliminating poverty and insecurity among vulnerable segments of the society, through comprehensive planning that promotes the integration and inclusion of new urban residents and all social groups.

Urban planning of intermediary cities is particularly complex for the reasons outlined in our paper. As in the case of Montes Claros, these cities face issues that must resolve if they are to succeed in promoting the type of sustainable development targeted by Brazilian legislation.

The first key challenge is the extremely rapid population growth these cities are facing. In the case of Montes Claros, which serves as a multi-dimensional activities hub for the northern part of the state, the intense and continuous flow of rural migrants has led to the creation of new subdivisions on the city fringes. These subdivisions are poorly equipped and poorly integrated in the urban community. It is therefore imperative that local authorities endeavor to integrate this dimension in the current urban planning. Otherwise, spatial fragmentation and social segregation are likely to continue to grow.

The second issue Montes Claros must address-like most intermediary cities that act as employment/service centers for the surrounding rural area-is that of spatial organization, which must be designed in coherence with this rural-urban interface by understanding the various dimensions that impact both rural and urban populations, as well as the natural and built environments. The public authorities in Montes Claros must quickly address the environmental problems the city faces, be it water (supply and flooding), deforestation or contamination (particularly through a more streamlined management of household/industrial waste).

The third key element is that of citizen participation in decision-making processes, especially in defining and 
implementing new urban planning. We noted that the current process has tended to favor certain stakeholders in the designing of this new urban planning phase (economic representatives, professional associations, universities, etc.). This stems from the fact that the process was not designed using a bottom-up approach designed to promote the participation of all residents in all neighborhoods, to identify problems and their desires in order to integrate them in the planning process. Analysis by experts would also help in determining priorities by considering the municipality's perspective from all areas: downtown, peri-urban and rural. Failing to do so is likely to both alienate people from political life and result in a spatial plan that is incoherent and non-inclusive.

Rapidly growing, intermediary cities in emerging countries like Brazil, or in developing countries, are once again on the agendas of national governments and internationals agencies. However, the challenge-beyond rhetoric and sweeping principles-is to better define what intermediation means exactly, in order to translate it into analytical tools for public action.

\section{Acknowledgements}

My sincere thanks go to Professor Iara Soares de França and the student Francielle Gonçalves Silva, Laboratório de Estudos Urbanos e Rurais-LAEUR, Departamen to de Geociências, Unimontes, Montes Claros, Brasil, for their contribution, advices and revision of the text.

\section{References}

ACI (Associação Comercial, Industrial e de Serviços de Montes Claros) (2012). Montes Claros. Potencialidades. Montes Claros: ACI.

Aguayo-Téllez, E., Muendler, M.-A., \& Poole, J. P. (2010). Globalization and Formal Sector Migration in Brazil. World Development, 38, 840-856. http://dx.doi.org/10.1016/j.worlddev.2010.02.018

Amorim, F., \& Serra, O. R. V. (2001). Evolução e perspectivas do papel das cidades medias no planejamento urbano e regional. In T. A. Andrade, \& R. V Serra (Eds.), Cidades medias brasileiras (pp. 1-34). Rio de Janeiro: IPEA.

Appert, M. (2008). Ville globale versus ville patrimoniale? Des tensions entre libéralisation de la skyline de Londres et préservation des vues historiques. Revue Géographique de l'Est, 48. http://rge.revues.org/1154

Bolay, J.-C., \& Kern, A. L. (2016). Intermediary Cities. In Wiley-Blackwell Encyclopedia of Urban and Regional Studies. Hoboken, NJ: Wiley-Blackwell. (In Press)

Bolay, J.-C., \& Rabinovich, A. (2004). Intermediary Cities in Latin America, Risks and Opportunities of Coherent Urban Development. The International Journal of Urban Policy and Planning, 21, 407-421.

Bolay, J.-C., Rabinovich, A., \& de la Porte, A. (Eds.) (2004). Interfase urbano-rural en Ecuador, hacia un desarrollo territorial integrado. Lausanne: Cahier du LaSUR 5, LaSUR/INTER/ENAC/EPFL.

Castañeda, F., Cloke, J., \& Brown, E. D. (2011). Latin American Cities in Globalization. In P. J. Taylor, N. Pengfei, B. Derudder, M. Hoyler, J. Huang, \& F. Witlox (Eds.), Global Urban Analysis: A Survey of Cities in Globalization (pp. 170-186). London and Washington DC: Earthscan.

Cohen, B. (2006). Urbanization in Developing Countries: Current Trends, Future Projections, and Key Challenges for Sustainability. Technology in Society, 28, 63-80. http://dx.doi.org/10.1016/j.techsoc.2005.10.005

Cohn, S. (2012). Employment and Development under Globalization: State and Economy in Brazil. New York, London: Springer. http://dx.doi.org/10.1057/9781137001412

de Oliveira, H. C. M. (2009). Cidades médias: Contribução para o debate. XI simposio nacional de geografia urbana, Brasilia: Universidade de Brasilia.

de Oliveira, H. C. M., \& Ribeiro Soarez, B. (2014). Cidade media: Apontamentos metodológicos e tipologia. Caminhos de Geografia, 15, 119-133. http://www.seer.ufu.br/index.php/caminhosdegeografia/article/view/23678

Esdras Leite, M. (2010). Favelas em cidades medias: Algumas considerações. Caminhos de Geografia, 34, 162-173. http://www.ig.ufu.br/revista/caminhos.html

Feitosa, F. F., Bao, L. Q., \& Vlek, P. L.G. (2011). Multi-Agent Simulator for Urban Segregation (MASUS): A Tool to Explore Alternatives for Promoting Inclusive Cities. Bonn: Center for Development Research (ZEF), University of Bonn.

Fernandes, E. (2007) Implementing the Urban Reform Agenda in Brazil. Environment and Urbanization, 19, 177-189. http://dx.doi.org/10.1177/0956247807076724

Ferré, C., Ferreira, F. H. G., \& Lanjouw, P. (2012). Is There a Metropolitan Bias? The Relationship between Poverty and City Size in a Selection of Developing Countries. The World Bank Economic Review, 26, 351-382. http://dx.doi.org/10.1093/wber/lhs007 
Gomez, S. P., \& Lamberts, R. (2009). O estudo do clima urbano e legislaçao urbanistica: Consideraçôes a partir do caso de Montes Claros. Ambiente Construido, 9, 73-91.

IBGE: Instituto Brasileiro de Geografia e Estatística (2000). Censo 2000. www.ibge.gov.br

IBGE: Instituto Brasileiro de Geografia e Estatística (2010). Censo 2010. www.ibge.gov.br/

IBGE: Instituto Brasileiro de Geografia e Estatística (2015). CIDADES@. Minas Gerais, Montes Claros, Historico. http://cidades.ibge.gov.br/painel/historico.php?lang=\&codmun=314330\&search=minas-gerais|montes-claros|infograficos:historico

Klaufus, C. (2010). Watching the City Grow: Remittances and Sprawl in Intermediary Central American Cities. Environment and Urbanization, 22, 125-137. http://dx.doi.org/10.1177/0956247809359646

Leite, M., E., \& Pereira, A. M. (2005). Expansão territorial e os espaços de pobreza na ciade de Montes Claros. Anais do X encontro de geógrafos de America Latina-20 a 26 de março de 2005. São Paulo: Universidade de São Paulo.

McCann, P. (2008). Globalization and Economic Geography: The World Is Curved, Not Flat. Cambridge Journal of Regions, Economy and Society, 1, 351-370. http://dx.doi.org/10.1093/cjres/rsn002

Municipio de Montes Claros, procudaria juridica (2009). Ley $N^{\circ} 4.198$, de 23 de dezembre de 2009. Dispõe sobre o uso de ocupaao do solo no Municipio de Montes Claros e dá outras providências. Montes Claros: Municícipio de Montes Claros.

Municipio de Montes Claros, procudaria juridica (2011). Ley $N^{\circ} 4.428$, de 12 de novembro de 2011. Altera o zoneamento urbano estabelecido pela lei municipal N. 4.198 de 23 de dezembro de 2.009, e dá outras providências. Montes Claros: Município de Montes Claros.

Municipio de Montes Claros, procudaria juridica (2015). Ley $N^{\circ} 4.821$ de 05 de outubro de 2015. Altera o zoneamento urbano estabelecido pela lei municipal N. 4.198 de 23 de dezembro de 2.009, e dá outras providências. Montes Claros: Municícipio de Montes Claros.

Nadou, F. (2010). La notion de "villes intermediaries", une approche différenciée du rôle des villes moyennes: Entre structuration territoriale et spécificités socio-économiques (pp. 1-19). HAL.

https://halshs.archives-ouvertes.fr/halshs-00596204/

National Research Council (2003). Cities Transformed: Demographic Change and Its Implications in the Developing World. Washington DC: National Academies Press.

Polidoro, M., de Lollo, J. A., \& Barros, M. V. F. (2012). Environmental Impacts of Urban Sprawl in Londrina, Paraná, Brazil. Journal of Urban and Environmental Engineering, 5, 73-83.

Prefeitura de Montes Claros (2015). Aspectos gerais. Montes Claros: Prefeitura. http://www.montesclaros.mg.gov.br

Roberts, B. R. (2005). Globalization and Latin American Cities. International Journal of Urban and Regional Research, 29, 110-123. http://dx.doi.org/10.1111/j.1468-2427.2005.00573.x

Robinson, J. (2002). Global and World Cities: A View from off the Map. International Journal of Urban and Regional Research, 26, 531-554. http://dx.doi.org/10.1111/1468-2427.00397

Romanos, M., \& Auffrey, C. (Eds.) (2002). Managing Intermediary Size Cities: Sustainable Development in a Growth Region of Thailand. Paris, Heidelberg, New York, Dordrecht, London: Springer. http://dx.doi.org/10.1007/978-94-017-2170-7

Rossi, E. C., Beaverstock, J. V., \& Taylor, P. J. (2007). Transaction Links through Cities: “Decision Cities” and “Service Cities” in Outsourcing by Leading Brazilian Firms. Geoforum, 38, 628-642.

http://dx.doi.org/10.1016/j.geoforum.2006.11.005

Sassen, S. (2001). The Global City: New York, London, Tokyo. Princeton, NJ: Princeton University Press. http://dx.doi.org/10.1515/9781400847488

Satterthwaite, D., \& Tacoli, C. (2003). The Urban Part of Rural Development: The Role of Small and Intermediary Urban Centers in Rural and Regional Development and Poverty Reduction. London: IIED.

SERENCO (Serviços de Engenheria Consultiva) (2015). Plano municipal de saneamento básico referente a prestação dos serviços de abastecimento de água potável, de esgotamento sanitário, de drenagem e manejo das águas pluviais urbanas e de limpeza urbana e manejo de resíduos sólidos de Montes Claros. Montes Claros: SERENCO.

Smets, P., \& Salman, T. (2008) Countering Urban Segregation: Theoretical and Policy Innovations from around the Globe. Urban Studies, 45, 1307-1332. http://dx.doi.org/10.1177/0042098008090676

Soares Costa da Silveira, Y. M. (2005). Montes Claros - Centro polarizador no Norte de Minas: Um estudio de sua periferização. Communication à Anais do X encontro de Géografos de America Latina, Sao Paulo: Universidade de São Paulo. https://www.researchgate.net/publication/267775608_MONTES_CLAROS_-CENTRO_POLARIZADOR_NO_NORTE_ DE_MINAS_UM_ESTUDO_DE_CASO_DE_SUA_PERIFERIZACAO

Soares de França, I. (2012). Aglomeraçao urbana descontínua de Montes Claros/MG: Novas configurações socioespaciais. Montes Claros: Uberlândia, Instituto de Geografia/UFU. http://repositorio.ufu.br/handle/123456789/1247 
Soares de França, I. (2015). O processo de verticalização urbana em cidades médias e a produção do espaço em Montes Claros/MG. Boletim Gáucho de Geografia, 42, 584-610. http://seer.ufrgs.br/index.php/bgg/article/view/52944

Soares de França, I., \& Ribeiro Soares, B. (2007a). Expansão urbana em cidades médias: Uma reflexão o partir do núcleo e da área central de Montes Claros no Norte de Minas Gerais. Geo UERJ, 2, 47-63.

http://www.e-publicacoes.uerj.br/index.php/geouerj/issue/view/143

Soares de França, I., \& Ribeiro Soares, B. (2007b). O espaço intra-urbano de uma cidade média e suas centralidades: O exemplo de Montes no Norte de Minas Gerais. Caminhos de Geografia, 8, 75-94. http://www.seer.ufu.br/index.php/caminhosdegeografia/article/view/15571

Soares de França, I., Soares de Almeida, M. I., Trindade Queiroz, C. G., Ramos Meireles, S. C., \& Júnio Sampaio, D. (2014). Cidade vertical: Politicas públicas e os territórios da política. Comuniçao in IV Congreso em Desenvolvimento Social Mobilidades e Desenvolvimentos, Montes Claros: Universidade Estadual de Montes Claros.

Soares de Souza, V. C., \& Soares de França, I. (2011). Habitação e regularização fundiária em Montes Claros. OBSERVATORIUM: Revista Eletrônica de Geografia, 3, 43-66. http://www.observatorium.ig.ufu.br/dezembro2011.htm

Soares Gonçalves, J. C. (2004). The Tall Building and the City: The Discussion about Urban Sustainability. Urban Design Quarterly, 91, 14-15. http://www.udg.org.uk/publications/urban-design-journal-issue/urban-design-91-summer-2004

Soares, P. R. (2006). Cidades médias e aglomerações urbanas: A nova organização do espaço regional no Sul do Brasil. In E. S. Sposito, M. E. B. Sposito, \& O. Sobarzo (Eds.), Cidades médias: Produção do espaço urbano e regional (pp. 347-364). São Paulo: Expressão Popular.

Sposito, M. E. B. (2001). As cidades médias e os contextos econômicos contemporâneos. In M. E. B. Sposito (Eds.), Urbanizaçao e cidades: Perspectivas geográficas. Presidente Prudente (pp. 609-643). Sao Paulo: GASPERR/FCT/UNESP.

UCLG (Global Network of Cities, Local and Regional Governments) (2016). Intermediary Cities in the New Urban Agenda. Barcelona: UCLG. https://www.uclg.org/en/media/news/intermediary-cities-new-urban-agenda

UCLG (Global Network of Cities, Local and Regional Governments) (2013). Planning for Sustainable Urban Development of Intermediary Cities. Barcelona: UCLG. https://issuu.com/uclgcglu/docs/eng_frame_document_i_cities_uclg_il

United Nations, Department of Economic and Social Affairs, Population Division (2014). World Urbanization Prospects. The 2014 Revision. New York: United Nations.

Veja (2011). Especial Cidades. No. 146, 2 de Novembro 2011, Sao Paulo: Abril Comunicações S.A. 